KOMMENTAR

INDHOLD

DETTE MATERIALE ER OPHAVSRETSLIGT BESKYTTET OG MÅ IKKE VIDEREGIVES 
RENÉ RASMUSSEN

\section{NÅR LITTERATER DIAGNOSTICERER}

BENJAMIN JON BOYSEN

\section{“Når psykiateren har brug for en psykiater"}

K\&K - Kultur og Klasse, nr. III, 2011

Benjamin Jon Boysen retter i sin artikel "Når psykiateren har brug for en psykiater" en meget skarp kritik mod Lacans ideer om James Joyce. Hans hovedtese er således, at Lacan har projiceret sin galskab over i Joyce, hvilket er muliggjort af, at Lacan læser hans forfatterskab, især fremstillingen af Stephen Dedalus, som udtryk for Joyce selv. Selvom Boysen ikke siger det eksplicit, indbefatter dette, at Lacan må være psykotisk, fordi han skulle hævde det tilsvarende om Joyce i henhold til en devise om, at den, som sygdommen lugte kan, er sygdommens ejermand. Boysen benytter begreberne spejling og projektion i en form for populær psykologisk forklaring. Det er på mange måder en problematisk og uvederhæftig tese, som bygger på en række kunstgreb fra Boysens side. Lad mig opsummere en række af disse og samtidig vise, at Boysens forståelse af Lacans seminar (Le sinthome), hvori han omtaler Joyce og dennes litteratur, glipper på radikal vis.

\section{Boysens biografisme}

Boysen hævder, at Lacan sammenblander Stephen Dedalus og Joyce, men Lacan anfører faktisk også, at Joyce latterliggør Stephen, - så større er sammenblandingen altså ikke. Men for at afvise Lacans såkaldte sammenblanding inddrager Boysen bl.a. en række citater fra Ulysses og Finnegans Wake $(F W)$, som skulle vise det modsatte. Det er yderste mærkværdigt: Hvor Lacan, iflg. Boysen, ikke kan bruge Stephen som udtryk for Joyce, kan Boysen bruge udsagn i Joyces tekster som udtryk for, at Joyce tager afstand fra Stephen. Når f.eks. Buck Mulligan kritiserer Stephen, er det, iflg. Boysen, udtryk for Joyces kritik af Stephen (Boysen 43). Buck Mulligan er her lig med Joyce. Lacan må altså ikke lave en biografisk læsning, mens Boysen gerne må.

Det er i øvrigt interessant, at Boysen kun fremhæver Joyces egne positive udsagn om sin fader efter dennes død som belæg for, at hans fader var god nok, mens Lacan anfører, at han var en mangelfuld fader i symbolsk henseende (jf. Lacans idé om det symbolske). Det gør Boysen med Joyce-citater fra Richard Ellmans berømte biografi om Joyce, men enhver seriøs biografi, herunder Ellmans og Brenda Maddox' om Nora Joyce (som Boysen også refererer til), vidner om det utroværdige ved disse udsagn om faderen.

Boysen kan i øvrigt ikke forstå, hvorfor Lacan anfører, at Joyce skulle have haft en "slap pik", men, som det bl.a. fremgår af Maddox' biografi, var Joyce til tider besat af ekstrem jalousi i forhold til Nora - en jalousi som Maddox betegner som "paranoid" (Maddox 93) - og han taler desuden om sek- 
suel afstraffelse i sine breve til hende. Den "slappe pik" eller fallos, som Lacan taler om, har en relation til Joyces tvivl om sin egen mandighed i forhold til Nora, og er ikke funderet i, hvorvidt han er potent eller ej, når han er sammen med hende. Det drejer sig om den symbolske værdi knyttet til Joyces mandighed eller mangel herpå, ikke om den konkrete potens eller mangel herpå.

Som belæg for sin egen biografisk funderede læsning af Lacans posthumt udgivne og redigerede seminar (Le sinthome) inddrager Boysen primært Elisabeth Roudinescos biografi om ham. Selvom den nogle steder rummer næsten rimelige teoretiske fremstillinger af Lacans ideer, er den det meste af tiden på niveau med Se og Hør. Samme Roudinesco er i øvrigt lige blevet dømt i retten i Paris for at have fremsagt fejlagtige oplysninger omkring ham og dennes begravelse. Hvor Lacan i det mindste havde læst samtlige af Joyces værker, den vigtigste sekundærlitteratur om ham og havde konsulteret førende Joyce-eksperter i Paris, bygger Boysen primært sin diagnose på en sladderbiografi.

Boysens opfattelse af galskaben (i Joyce)

A) Boysen antager rask væk, at Lacan mener, at Joyce var psykotisk, men faktisk siger han intet sted, at dette er tilfældet, ligesom han ikke anfører, at Joyce var megaloman eller led af mani. Derimod hævder han, at $F W$ minder om mani, men det er ikke det samme som, at Joyce skulle have lidt af det. Her som en række andre sted fejllæser eller reducerer Boysen derfor rækkevidden af Lacans udsagn. Det udeluk- ker ikke, at det er muligt at udlægge Lacans seminar som, at Joyce led af en psykose, men aldrig havde et udbrud af den, fordi hans litteratur udgjorde en stabiliserende faktor, men en sådan udlægning burde forklares.

Det er i øvrigt her, at Lacan og psykoanalysen kan lære af Joyces liv og værk. Lacan læser nemlig ikke så meget Joyce for at fortælle noget om hans "psykose", men for at lære noget om, hvordan det er muligt for et subjekt med en psykotisk struktur at finde en stabilisering i sine skriverier. Ikke for alle subjekter, men for nogle. Boysen viser også her en manglende indsigt $i$, hvad et psykotisk sprog skulle være, nemlig et opløst sprog, hvad FW dog ikke er (Boysen 3I). Et psykotisk sprog behøver på ingen vis at være et opløst sprog og kan minde om såvel $F W$ som om en række lettere tilgængelige tekster.

Dette udelukker imidlertid ikke Boysen fra at hævde, at Lacans "galskab" skulle vise sig $i$, at han begynder at tale og skrive i stil med $F W$ (37), hvormed $F W$ alligevel kommer til at fremstå som en protype på psykotisk sprog.

B) Det er rigtigt, at Lacan sammenligner sig med Joyce en række steder, men denne sammenligning skal ikke forstås som en narcissistisk identifikation, som Boysen hævder, men som, at Joyce på nogle (men ikke alle) punkter indtager en position, der minder om psykoanalytikerens i en analyse. "Sinthome", der bl.a. kan læses som "saint homme" (helgen), er således ikke kun en betegnelse, som Lacan benytter om Joyce, men tillige om psykoanalytikerens po- 
sition i kuren. Ikke en helgen i kristen forstand, men snarere i en buddhistisk forstand, eftersom det drejer sig om at være tømt for mærkværdige forestillinger og følelser, når man lytter til analysandens tale.

I øvrigt sammenligner Lacan sig et andet sted med Marguerite Duras og andre steder med Sigmund Freud. Disse sammenligninger er heller ikke narcissistiske identifikationer.

C) Da Boysen tilsyneladende ikke har øjne for, at Le Sinthome faktisk handler om mere end Joyce, er han ikke opmærksom på, at en række af de begreber, som Lacan benytter, drejer sig om meget mere. Det er f.eks. tilfældet med selve ordet "sinthome", der ikke kun vedrører Joyce, men bl.a. dækker over en idé om, at der efter en afslutning af en analytisk kur altid vil være et særligt symptom tilbage, som ikke kan analyseres videre eller bort. Det betyder, at alle, som har gennemført en analyse, herunder analytikeren selv, har sit særlige symptom: sit sinthome. Det er et sinthome, der på særlig vis knytter sprog og krop sammen eller som sammenknytter de tre ordner (den symbolske, det imaginære og det reelle), som Lacan opererer med. Derfor findes sinthome både hos psykotiske og neurotiske subjekter. For Joyces vedkommende havde dette sinthome tilmed en så tilpas karakter, at han ikke behøvede at gå i analyse. Det er bl.a. derfor, at Lacan anfører, at Joyce havde opsagt sit abonnement på det ubevidste. Dette har absolut ikke, som Boysen misforstår det, noget at gøre med, at han skulle have forkastet alle menneskelige bånd (45).
D) Når Boysen imidlertid selv vil forstå psykosen, nemlig Joyces datter, hvis sygdom Boysen vedkender sig, er skizofreni, henfører han den til en genetisk sammenhæng og gentager uden nogen forbehold biologismens ideer om genetik (30). Og da Joyces egen familie ikke udviser nogen eksempler på skizofreni, må den ergo stamme fra Noras familie, hvori der er flere eks. herpå. Galskab er altså genetisk betinget, og Joyce var ikke ramt af denne, men det er Lacan, når han identificerer sig med Joyce og når hans sprog bliver ligesom i $F W$.

Den identifikation eller spejling, som Boysen her opererer med mellem Lacan og Joyce, er imidlertid ikke genetisk bestemt. I hvert fald forklarer Boysen det ikke som et genetisk fænomen, men med Roudinesco som et spørgsmål om Lacans egen familiære baggrund (fader, moder osv.). Hvor Boysen bruger den genetiske model (og Joyces egne udsagn om sin fader) som argument for, at Joyce ikke var psykotisk, bruger han udelukkende den biografiske model til at forklare, hvorfor Lacan var det i sin identifikation med Joyce. Da jeg ikke er i familie med Lacan, vil jeg lade det injurierende ved denne grundantagelse om hans galskab ligge (det må hans efterladte klare, hvis de synes), men denne diagnose står i vejen for, at Lacans ideer faktisk udgør nogle af de mest revolutionerende inden for psykoanalysen siden Freud og at de formentlig er de mest udbredte siden Freud. Lige så problematisk er det, at Boysen uden videre glider rundt i sin argumentation, når han vil diagnosticere ham og frelse Joyce for den fornedrelse, som Lacan skulle have påført ham. Boysen overser, at hvis Joyce og 
en række andre forfattere (Pound, Artaud, Celan osv.) lider af en særlig galskab, så rykker det intet ved deres værkers kunstneriske værdi.

E) Helt grotesk bliver det, når Boysen efter flere sider har forsøgt at tilbagevise, hvad han forstår som Lacans påstand om Joyces megalomani, alligevel giver Lacan "ret" (i henhold til Boysens idé om, hvad han nu skulle mene): Joyce var "selv ganske megaloman" (44), og han mente selv, "at det var kunsten, der skabte tilværelsen og ikke omvendt" (44). Sidste sætning er faktisk en forenklet udgave af hovedtesen i Lacans forståelse af Joyces kunst og investering i sit værk: At det var med kunsten, at han skabte sig sit liv og blev til det navn, som skulle optage os i århundreder. Men ikke alene giver han Lacan ret, men Boysen dementerer også sine egne udsagn om, at Joyce definitivt skulle have taget afstand fra Stephens lignende tanker.

\section{Boysens "hermeneutiske" loesning af Lacan}

Boysen starter sin diagnose af Lacan med at anføre, at denne ikke læser Joyce på hermeneutisk vis, idet "han ikke tilføjer teksten noget” og “den ikke tilføjer ham noget" (28-29). Det samme kan hævdes om Boysens læsning af Le Sinthome. Han tilføjer ikke noget til den tekst, og han lærer intet af den, men læser den ud fra sladderhistorier og med diagnosticerende briller. I øvrigt bør det bemærkes, at Lacan naturligvis ikke er hermeneutiker, og som det fremgår ovenfor, er hans læsning af Joyce ikke et forsøg på bruge psykoanalysen i en særlig tekstlæsning. Psy- koanalysen kan kun benyttes i det analytiske rum, og derfor er hans læsning og fortolkning et forsøg på at lære af Joyce og hans værk.

Hvis Boysen imidlertid havde sat sig lidt mere ind i, hvordan Lacan benytter og videreudvikler Freuds forståelse af symptomet med begrebet sinthome, ville han også have set, at dette sinthome både udgør en form for symptom og en kunstnerisk skabelse. Freud forstod derimod sidstnæunte som en opløsning af symptomet i en form for sublimering, men Lacan peger på, at det symptom (sinthome), som ikke kan analyseres videre i psykoanalysen, både udgør en form for symptom og en form for sublimering. Joyces livsværk er et eminent eks. herpå. I en psykoanalytisk sammenhæng er det helt klart, at hans ideer om Joyce kan være berigende for et arbejde med såvel psykotiske som neurotiske patienter samt for afslutningen af en analyse.

Men disse ideer rykker fortsat ikke ved den kunstneriske værdi af Joyces tekster. Jeg startede tilmed at læse Joyce, fordi Lacan gjorde det. Og for mig at se er Ulysses verdens bedste bog (selvom jeg kun har læst en brøkdel af de bøger, som eksisterer), som jeg med glæde genlæser gang på gang. Det udelukker dog ikke, at jeg, ligesom store dele af Joyce-forskningen eller Joyceindustrien, som denne forskning har døbt sig selv, også mener, at FW er ulæselig eller kedelig, medmindre man læser den som digte, som meget svære digte. Men det er en helt anden historie. 


\section{Litteraturliste}

Boysen, Benjamin Jon. "Når psykiateren har brug for en psykiater". K๘ K - Kultur og Klasse, nr. III (2OII): 27-48.

Ellmann, Richard. James Joyce. Oxford: Oxford University Press, 1983.

Lacan, Jacques. Le Sinthome. Paris: Seuil, 2005.

Maddox, Brenda. Nora. The real life of Molly Bloom. Boston: Houghton Mifflin Company, I988.

Roudinesco, Élisabeth. Jacques Lacan. Paris: Fayard, I993.
René Rasmussen er lektor på Institut for Nordiske Studier og Sprogvidenskab, Kobenhavns Universitet. Har bl.a. udgivet: Slut. Begynd! En psyko-narrativ læsning af James Joyce: "Ulysses" (Forlaget Politisk Revy, 1996) og Lacan, sprog og seksualitet (Forlaget Spring, 2009). 